\title{
Protective effects of lutein against vancomycin-induced acute renal injury in mice via upregulation of peroxisome proliferator- activated receptor gamma/nuclear factor erythroid 2-related factor $\mathbf{2}$ and inhibition nuclear factor-kappaB/caspase 3
}

\author{
Promise M. Emeka ${ }^{1, *}$, Sahibzada T. Rasool ${ }^{2}$, Mohamed A. Morsy ${ }^{1,3}$, Mohamed I. Hairul Islam , \\ and Muhammad S. Chohan ${ }^{2}$ \\ Departments of ${ }^{1}$ Pharmaceutical Sciences and ${ }^{2}$ Biomedical Sciences, College of Clinical Pharmacy, King Faisal University, Al-Ahsa 31982, Saudi Arabia, \\ ${ }^{3}$ Department of Pharmacology, Faculty of Medicine, Minia University, El-Minia 61511, Egypt, ${ }^{4}$ Department of Biological Sciences, College of Science, King \\ Faisal University, Al-Ahsa 31982, Saudi Arabia
}

\section{ARTICLE INFO}

Received October 26, 2020

Revised March 10, 2021

Accepted April 5, 2021

*Correspondence

Promise M. Emeka

E-mail: pemeka@kfu.edu.sa

Key Words

Acute renal injury

Caspase-3

Lutein

PPAR gamma

Vancomycin

\begin{abstract}
Vancomycin, an antibiotic used occasionally as a last line of treatment for methicillin-resistant Staphylococcus aureus, is reportedly associated with nephrotoxicity. This study aimed at evaluating the protective effects of lutein against vancomycin-induced acute renal injury. Peroxisome proliferator-activated receptor gamma (PPARy) and its associated role in renoprotection by lutein was also examined. Male $\mathrm{BALB} / \mathrm{c}$ mice were divided into six treatment groups: control with normal saline, lutein $(200 \mathrm{mg} / \mathrm{kg})$, vancomycin $(250 \mathrm{mg} / \mathrm{kg})$, vancomycin $(500 \mathrm{mg} / \mathrm{kg})$, vancomycin $(250 \mathrm{mg} / \mathrm{kg})$ with lutein, and vancomycin $(500 \mathrm{mg} / \mathrm{kg})$ with lutein groups; they were euthanized after 7 days of treatment. Thereafter, samples of blood, urine, and kidney tissue of the mice were analyzed, followed by the determination of levels of $\mathrm{N}$-acetyl$\beta$-D-glucosaminidase (NAG) in the urine, renal creatine kinase; protein carbonyl, malondialdehyde, and caspase-3 in the kidney; and the expression of PPAR $\gamma$, nuclear factor erythroid 2-related factor 2 (Nrf2), and nuclear factor-kappaB (NF- $\kappa$ B) in renal tissue. Results showed that the levels of protein carbonyl and malondialdehyde, and the activity of NAG, creatine kinase and caspase-3, were significantly increased in the vancomycin-treatment groups. Moreover, the levels of Nrf2 significantly decreased, while NF- $\kappa$ B expression increased. Lutein ameliorated these effects, and significantly increased PPAR $\gamma$ expression. Furthermore, it attenuated vancomycin-induced histological alterations such as, tissue necrosis and hypertrophy. Therefore, we conclude that lutein protects against vancomycin-induced renal injury by potentially upregulating PPAR//Nrf2 expression in the renal tissues, and consequently downregulating the pathways: inflammation by NF- $\mathrm{KB}$ and apoptosis by caspase-3.
\end{abstract}

\section{INTRODUCTION}

Kidneys are the main excretory organ for many drugs, and could easily be exposed to toxins. Nephrotoxicity has been reported to contribute to approximately $8 \%-40 \%$ of all cases of acute renal injury. Since its introduction, vancomycin, a glycopeptide antibiotic often used as the last line of defense against drug resistant gram-positive bacteria, has been associated with acute renal injury $[1,2]$. Vancomycin is commonly used to treat hospitalacquired methicillin-resistant Staphylococcus aureus (MRSA)

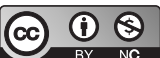

This is an Open Access article distributed under the terms of the Creative Commons Attribution Non-Commercial License, which permits unrestricted non-commercial use, distribution, and reproduction in any medium, provided the original work is properly cited. Copyright @ Korean J Physiol Pharmacol, pISSN 1226-4512, elSSN 2093-3827
Author contributions: P.M.E. contributed to conception and design, acquisition and analysis of data, and drafted the manuscript. S.T.R., M.A.M., and M.I.H.I. contributed to the acquisition and analysis of data and critically revised the manuscript for important intellectual content. M.S.C. substantially contributed to the acquisition and analysis of data and drafted the manuscript. 
infections [1]. Due to treatment failures, clinicians have been reported to be using higher doses of vancomycin [3]. Although the use of high-dose regimens of vancomycin is not approved by regulatory authorities, it is often administered to achieve a trough of $15-20 \mathrm{mg} / \mathrm{L}$ due to the emerging drug resistance; it is believed to be clinically effective against drug-resistant bacteria [4]. The results of cohort and retrospective studies have reported rising rates of nephrotoxicity due to the increased use of high-dose vancomycin $[4,5]$. An earlier report indicated that vancomycininduced nephrotoxicity is associated with oxidative stress [6]; thereby, establishing that high-dose vancomycin leads to the generation of reactive oxygen species that disrupt antioxidant activity [7]. Production of oxyradicals in the state of oxidative stress can cause cellular damage that can lead to renal injury and cell death [8]. Studies show that, the molecular components for the function and regulation of cell-signaling, which are susceptible to oxidative stress, are altered under these conditions [9]. Despite the evidence implicating oxidative stress in vancomycin-induced renal injury, the underlying mechanism of the process is still unclear. A better understanding of this mechanism would help in planning a better therapeutic management, as vancomycin is still the first-line drug for both hospital- and community-acquired MRSA infections [5].

Lutein is a carotenoid that has been reported to modulate proinflammatory mediators, such as the peroxisome proliferatoractivated receptors (PPAR), which is known to generate oxyradicals that alter signaling transduction pathways [10]. PPAR $\gamma$, a transcription factor and a member of the PPAR family, has been found to be expressed in renal tissues, and is implicated in the regulation of redox hemostasis in the kidney [11]. PPAR $\gamma$ activity is said to be well-regulated during various cellular processes; indeed, nuclear factor-kappaB (NF- $\kappa$ B) stimulation has shown to often suppress PPAR $\gamma$ activity [12]. PPAR $\gamma$ agonists reportedly decrease NF- $\kappa \mathrm{B}$ activity in many tissues during inflammation [11]. Activation of PPAR $\gamma$ could be useful against renal damage induced by oxidative stress through the inhibition of NF- $\kappa \mathrm{B}$ protein expression, possibly via multiple mechanisms. Lutein was shown to enhance PPAR $\gamma$ levels, when administered to enhance anti-inflammatory responses in chickens [13]. Agents that target PPAR $\gamma$ have been shown to mediate inflammatory activities in both animals and humans [14]. Studies have shown that lutein activates the antioxidant response element transcription system, which might explain the anti-cancer properties of carotenoids that has been reported $[10,15]$. However, the mechanism of antioxidant effect by lutein in renal injury is still debatable and could be multifactorial. Here, we hypothesized that lutein could activate PPAR $\gamma$ in the kidney, through which it could attenuate the oxidative effects of oxyradicals. Therefore, the objectives of this study were to: (a) evaluate the protective effects of lutein in vancomycin-induced acute renal injury in mice, and (b) examine PPAR $\gamma$ expression and the associated signaling pathways in mice with vancomycin-induced renal injury, using Western blotting and real-time polymerase chain reaction (PCR).

\section{METHODS}

\section{Chemicals, assay kits, and antibodies}

Vancomycin was supplied by Julphar (Ras Al Khaimah, UAE), and lutein was supplied by Extrasynthese (Genay, France). Assay kits for $\mathrm{N}$-acetyl- $\beta$-D-glucosaminidase (NAG), protein carbonyl content, and caspase-3 were purchased from Sigma-Aldrich (St. Louis, MO, USA). Primary antibodies against PPAR $\gamma$, nuclear factor erythroid 2-related factor 2 (Nrf2), and NF-кB p65 were purchased from Santa Cruz Biotechnology (Dallas, TX, USA). Gels for Western blotting were procured from Bio-Rad (Hercules, CA, USA), and primers for real-time PCR of PPAR $\gamma$ were procured from Gibco, Thermo Fisher Scientific Inc. (Waltham, MA, USA).

\section{Animals}

Male BALB (Bagg Albino)/c mice with an average weight of $29.5 \mathrm{~g}$, were obtained from the Department of Biological Sciences, College of Science, King Faisal University, Saudi Arabia. The mice were maintained in groups of six per cage in controlled environmental conditions according to the specified standards, with $12 \mathrm{~h}$ dark and $12 \mathrm{~h} \mathrm{light}$ cycle, at $23 \pm 1^{\circ} \mathrm{C}$. They were allowed access to food and water throughout the study. Animal care and experimental procedures were carried out according to the guidelines of the Research Ethics Committee at King Faisal University (140237/27/2013) and that of the National Committee of Bioethics (NCBE), King Abdulaziz City for Science and Technology (KACST), Saudi Arabia.

\section{Experimental protocol}

The mice were divided into six groups (six mice per group) as follows: control with normal saline, lutein (L: lutein) $200 \mathrm{mg}$ / $\mathrm{kg}$ (dissolved in $0.2 \%$ dimethyl sulfoxide [DMSO]), vancomycin $250 \mathrm{mg} / \mathrm{kg}$ (low-dose vancomycin: $\mathrm{VL}$ ), $500 \mathrm{mg} / \mathrm{kg}$ vancomycin (high-dose vancomycin: VH), L + VL, and L + VH. Both the drugs were administered intraperitoneally and consecutively for 7 days, according to the modified methods described by Qu et al. [16], Nakamura et al. [17], and Vasudeva et al. [18]. Vancomycin was given $30 \mathrm{~min}$ after lutein administration. At the end of the study, mice were euthanized by cervical dislocation under mild anesthesia. The blood samples, 24 -h urine samples, and harvested kidneys were collected at the same time, and stored at $-85^{\circ} \mathrm{C}$ for analysis. The collected samples were used for estimation of biochemical markers of renal injury, such as NAG, creatinine kinase, protein carbonyl, and caspase-3. Western blotting was performed to analyze the expression of PPAR $\gamma$, Nfr2, and NF-кB p65. Realtime PCR was also used to analyze the expression of PPAR $\gamma$ in the harvested kidneys from all the groups. 


\section{Urinary assay of NAG}

NAG activity in the urine samples was evaluated using an enzymatic assay, according to the manufacturer's instructions. As reported by Horak et al. [19], the assay was based on the hydrolysis of 4-nitrophenyl N-acetyl- $\beta$-D-glucosaminide by NAG that releases $\mathrm{p}$-nitrophenol with a basic $\mathrm{pH}$, leading to the formation of the yellow-colored p-nitrophenylate ion, which was then measured colorimetrically at $405 \mathrm{~nm}$.

\section{Creatine kinase activity}

Creatine kinase activity was evaluated according to the method described by Hughes [20]. The tissue homogenates of the kidney was incubated in $50 \mathrm{mM}$ Tris buffer ( $\mathrm{pH} 7.5$ ), $7.5 \mathrm{mM} \mathrm{MgSO}_{4}, 7$ $\mathrm{mM}$ phosphocreatine, and $3.2 \mathrm{mM}$ ADP medium for $10 \mathrm{~min}$ at $37^{\circ} \mathrm{C}$. Then, $15 \mu \mathrm{l}$ of $1 \mathrm{mM}$ p-hydroxymercuribenzoic acid was added after the reaction was stopped for $10 \mathrm{~min}$. To analyze the reaction colorimetrically, $2 \% \alpha$-naphthol and $1 \%$ diacetyl were added; the reaction mixture was allowed to develop color for 15 $\min$ at $37^{\circ} \mathrm{C}$, and then measured at $540 \mathrm{~nm}$.

\section{Protein carbonyl content}

Protein carbonyl content, which is a marker of oxidative damage, was measured using a previously reported method [21]. The oxidized proteins produced protein carbonyl, which was then reacted with 2,4-dinitrophenylhydrazine to produce 2,4-dinitrophenylhydrazone, which was measured spectrophotometrically at $375 \mathrm{~nm}$.

\section{Malondialdehyde (MDA) level}

Lipid peroxidation (assessed based on MDA production) in the tissue homogenates of the kidney was measured by determining the levels of thiobarbituric acid-reactive substances, as described by Ohkawa et al. [22]. Phosphoric acid solution (1\%) and a known volume of thiobarbituric acid was added to each homogenate sample, and then incubated at $95^{\circ} \mathrm{C}$ for $1 \mathrm{~h}$. The concentration of the subsequent thiobarbituric acid-reactive substances was then measured spectrophotometrically at $535 \mathrm{~nm}$.

\section{Measurement of caspase-3 activity}

Caspase-3 activity was measured using a colorimetric assay, according to the manufacturer's instructions. The kidney tissues were homogenized in $3 \mathrm{ml}$ of $10 \mathrm{mM}$ phosphate buffer $(\mathrm{pH}$ 7.4) [23]. Detection of caspase-3 activity was predicated on the hydrolysis of the peptide substrate acetyl-Asp-Glu-Val-Asp pnitroanilide by caspase-3. The reaction led to the consequent release of the p-nitroaniline component, which was then measured spectrophotometrically at $405 \mathrm{~nm}$.

\section{Western blotting}

The protein expression of PPAR $\gamma, \mathrm{Nrf} 2$, and NF- $\mathrm{B}$ p 65 in the kidney tissues were determined through Western blotting using specific antibodies, according to the method described by Ahn et al. [24]. The harvested tissues were homogenized with radioimmunoprecipitation assay lysis buffer to isolate and extract the content of whole protein. The nuclear extracts were isolated and used for the determination of PPAR $\gamma, \mathrm{Nrf} 2$, and NF- $\kappa \mathrm{B}$ p65 expression. Approximately $50 \mu \mathrm{g}$ of protein samples were separated using 10\% Sodium dodecyl sulfate polyacrylamide gel electrophoresis gels. These were later transferred on to polyvinylidene fluoride membranes, and $5 \%$ non-fat dried milk was used to block the non-specific sites at $20-22^{\circ} \mathrm{C}$ for $1 \mathrm{~h}$. This was followed by washing of the membranes with Tris-buffered saline and $0.1 \%$ Tween 20 (TBST). The membranes were then incubated overnight at $4^{\circ} \mathrm{C}$ with primary mouse monoclonal antibodies against PPAR $\gamma, \mathrm{Nrf} 2$, and NF- $\kappa \mathrm{B}$ p65 in a ratio of 1:1,000. Thereafter, the membranes were washed with TBST, and incubated with secondary peroxidase-conjugated goat anti-mouse IgG in a ratio of 1:5,000 for 1 $\mathrm{h}$. The resulting bands were visualized according to the manufacturer's instructions, using an enhanced chemiluminescence system. ImageJ software (freeware; rsbweb.nih.gov/ij) was used to perform the densitometric analyses of the bands.

\section{Real-time PCR}

Quantitative real-time PCR was performed for expression analysis of PPAR $\gamma$ in the kidney tissues. cDNA was synthesized from the samples by using a previously reported method [25]. In brief, total RNA was isolated from kidney tissues using the TRIzol method (Gibco; Thermo Fisher Scientific), according to the manufacturer's instructions, and stored at $-85^{\circ} \mathrm{C}$ for later use. The oligonucleotide primers for PCR were as follows: PPAR $\gamma$, forward 5'-CGGTTTCAGAAGTGCCTTG-3', reverse $5^{\prime}$-GGTTCAGCTGGTCGATATCAC-3'; and $\beta$-actin forward 5'-AGCTATGAGCTGCCTGACGG-3', reverse 5'-CCAGACAGCACTGTGTTGG-3'. Using kinetic analysis of PCR amplification, the amounts of each template of PPAR $\gamma /$ $\beta$-actin mRNA were calculated. The PPAR $\gamma$ mRNA expression was standardized with that of $\beta$-actin mRNA, which was used for comparison with each sample. The relative expression of PPAR $\gamma$ was represented as fold change and determined by the relative quantification algorithm with the $2^{-\triangle \Delta C T}$ method [26].

\section{Histological examination}

The kidney tissues were fixed in $10 \%$ formaldehyde in phosphate-buffered saline. Later, the tissues were embedded in paraffin for light microscopic evaluation; they were sectioned and stained with hematoxylin and eosin. Slide preparation and a double-blinded evaluation were performed by a histopathologist. 
The results of pathology were indicated as follows: (-) absence of pathology, (+) mild pathology, (++) moderate pathology, $(+++)$ severe pathology, and $( \pm)$ recovery.

\section{Data analysis}

The results obtained were expressed as mean \pm SD; they were analyzed using the GraphPad Prism software version 8.2 (San Diego, CA, USA). Comparisons between all the treatment and control groups were made using the one-way analysis of variance, and the differences between the groups were measured using the Tukey's multiple comparison test. $\mathrm{p}<0.05$ was considered statistically significant.

\section{RESULTS}

\section{Effects of lutein on NAG, creatine kinase, protein carbonyl, MDA, and caspase- 3 activities}

Mice treated with VL and VH showed a significant elevation in NAG activity, which was significantly attenuated by co-admin- istration with lutein (Fig. 1A). In Fig. 1B, the activity of creatine kinase was significantly higher in VL- and VH-treatment groups, than that in the control group. In L $+\mathrm{VL}$ or $\mathrm{L}+\mathrm{VH}$ groups, creatine kinase had reduced significantly. As shown in Fig. 1C, the protein carbonyl content in VL and VH groups were significantly higher than those in the control group, and co-administration with lutein significantly reduced the protein carbonyl content in these treatment groups. MDA levels had increased significantly in the vancomycin-treatment groups than those in the control group. However, following co-administration with lutein, these levels had also decreased significantly (Fig. 1D). Caspase-3 activity in the kidney tissues had increased significantly in the VL- and VH-treatment groups than that in the control group. The activity had reduced significantly again, with the co-treatment of vancomycin with lutein in both the treatment groups (Fig. 1E). Our results indicate that lutein effectively increases the antioxidant activity in the kidney tissues. Subsequently, co-administration with lutein attenuated the injurious effects due to the administration of $\mathrm{VL}$ and $\mathrm{VH}$, respectively.
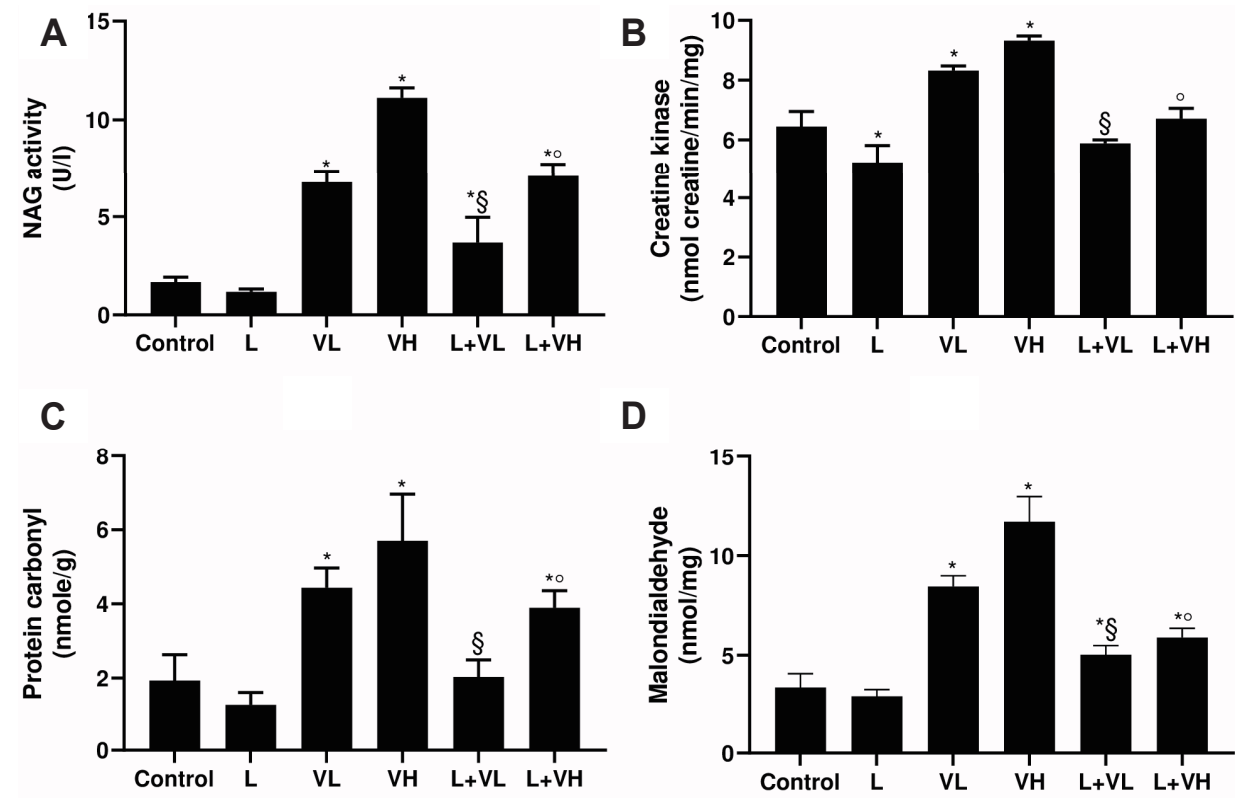

D
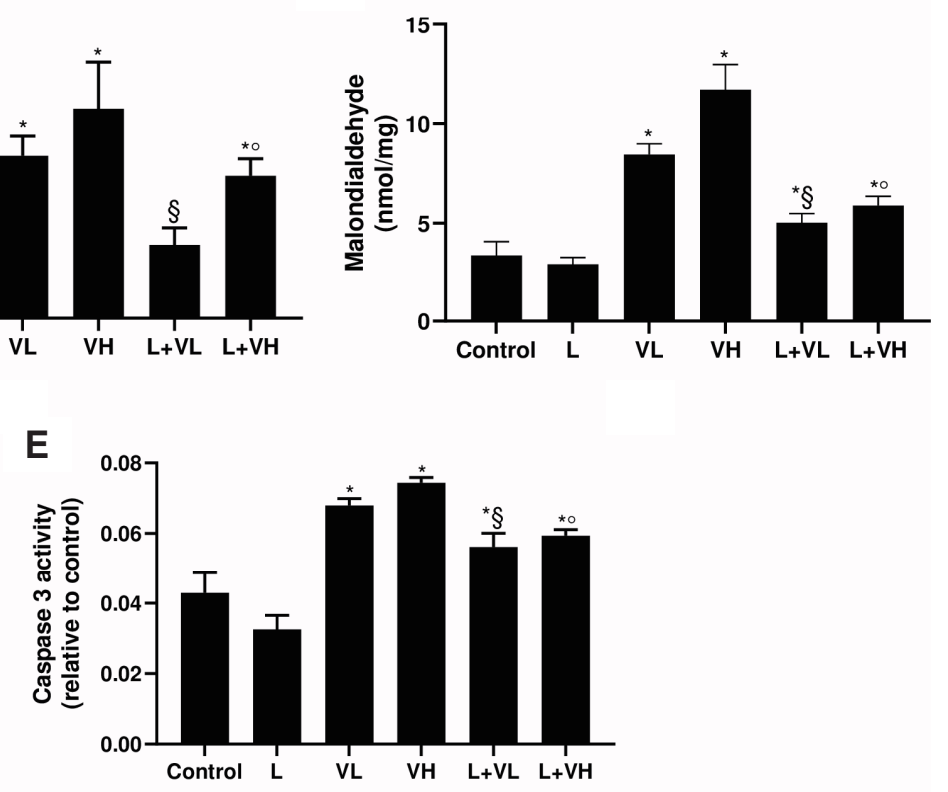

Fig. 1. Effect of lutein on (A) N-acetyl$\beta$-D-glucosaminidase (NAG), (B) creatine kinase, (C) protein carbonyl, (D) malondialdehyde, and (E) caspase-3, in low $(250 \mathrm{mg} / \mathrm{kg})$ and high $(500 \mathrm{mg} /$ $\mathrm{kg}$ ) dose vancomycin-induced renal injury in mice. Results are mean $\pm \mathrm{SD}$. $\mathrm{L}$, lutein $200 \mathrm{mg} / \mathrm{kg}$; VL, vancomycin $250 \mathrm{mg} / \mathrm{kg}$; VH, vancomycin $500 \mathrm{mg} / \mathrm{kg}$. *Shows significant different $(p<0.05)$ from control, while $s_{\text {indicates significant }}$ different $(p<0.05)$ from VL-treatment, and $\mathrm{VH}$-treatment groups, respectively. 


\section{Effect of lutein on histopathological changes induced by vancomycin}

In the control group and groups treated with lutein, the glomeruli and renal tubules showed no signs of cellular damage (Fig. $2 \mathrm{~A}, \mathrm{~B}$ ). In addition, there was no infiltration of inflammatory cells, and renal architecture was normal (Table 1). In the VLtreatment group, we observed abnormal dilation of renal tubules that were filled with leukocytes, in addition to significant infiltration of inflammatory cells into the renal parenchyma (Fig. 2C). However, in the L + VL-treatment group, there were reductions in infiltration of inflammatory cells, and recovery of the renal parenchyma (Fig. 2D and Table 1). Administration of $500 \mathrm{mg} / \mathrm{kg}$ vancomycin produced significant renal damage such as epithelial necrosis of the renal tubules, and complete obliteration of the tubules in most cases (Fig. 2E). Lutein administration to this group, significantly attenuated the injurious effects of vancomycin, indicating recovery of the renal tubules (Fig. 2F).

\section{Effects of lutein on PPAR (protein and mRNA) and Nrf2 expressions in vancomycin induced changes}

The expression levels of PPAR $\gamma$, (protein and mRNA) and Nrf2, determined in the control and treatment groups, are shown in Fig. 3A-C. Western blotting analysis showed a significantly increased PPAR $\gamma$ expression in the VL- and VH-treatment groups than that in the control group. In addition, co-administration with lutein in both VL- and VH-treatment groups further increased PPAR $\gamma$
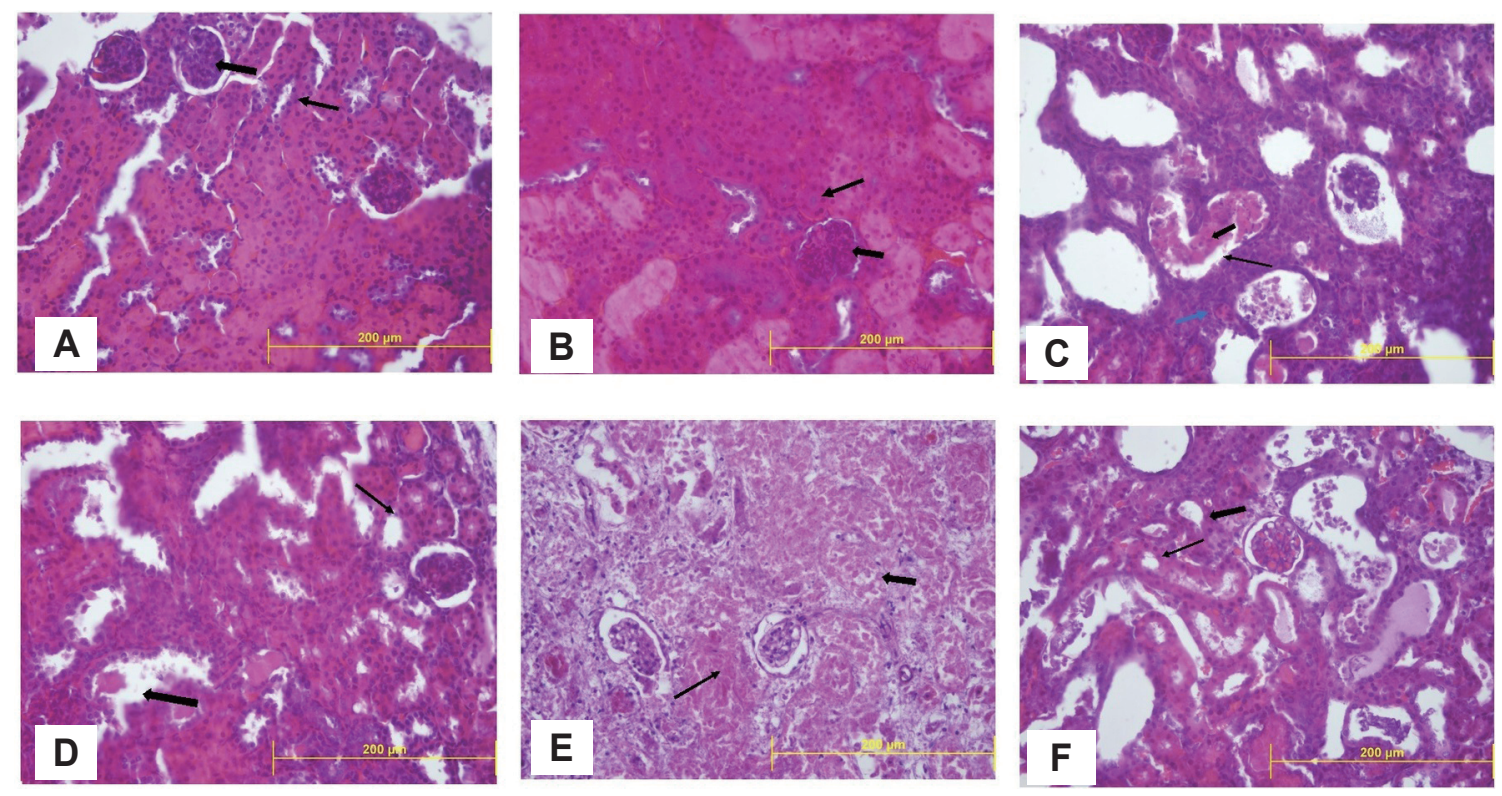

Fig. 2. Effect of lutein on histopathological changes in low $(250 \mathrm{mg} / \mathrm{kg})$ and high $(500 \mathrm{mg} / \mathrm{kg})$ dose vancomycin-induced renal injury in mice (A-F: H\&E $\times 40)$. In (A, B) thick black arrow: normal glomerulus, thin black arrow: normal renal tubules. (C) Thick black arrow: abnormal dilatation of the renal tubules, thin black arrow: renal tubules filled with leukocytes, blue arrow: infiltration of inflammatory cells in the renal parenchyma. (D) Showing recovery of the parenchyma of the kidney (thick arrow and thin black arrows). (E) Thick black arrow: obliteration of renal tubules filled with necrotic cells, thin black arrow: necrosis of the epithelium of renal tubules. (F) Thick and thin black arrows: showing recovery of the parenchyma of kidney with no observed necrosis of epithial lining of renal tubules.

Table 1. Histopathological scoring of the effect of lutein on low $(250 \mathrm{mg} / \mathrm{kg})$ and high $(500 \mathrm{mg} / \mathrm{kg})$ dose vancomycin-induced renal injury in mice

\begin{tabular}{|c|c|c|c|c|c|}
\hline Group & $\begin{array}{l}\text { Abnormal } \\
\text { dilatation of the } \\
\text { renal tubules }\end{array}$ & $\begin{array}{c}\text { Renal tubular } \\
\text { obliteration }\end{array}$ & Tubular necrosis & $\begin{array}{l}\text { Renal tubules } \\
\text { filled with } \\
\text { leukocytes }\end{array}$ & $\begin{array}{c}\text { Inflammatory cell } \\
\text { infiltration in } \\
\text { parenchyma }\end{array}$ \\
\hline Control & - & - & - & - & - \\
\hline Lutein & - & - & - & - & - \\
\hline Vancomycin $250 \mathrm{mg} / \mathrm{kg}$ & + & - & - & + & + \\
\hline Lutein + vancomycin 250 mg/kg & \pm & - & - & - & \pm \\
\hline Vancomycin 500 mg/kg & - & +++ & +++ & - & - \\
\hline Lutein + vancomycin 500 mg/kg & + & - & - & + & + \\
\hline
\end{tabular}

- , absence of pathology; +, mild pathology; ++, moderate pathology; +++, severe pathology; \pm , recovery. 


\section{A}
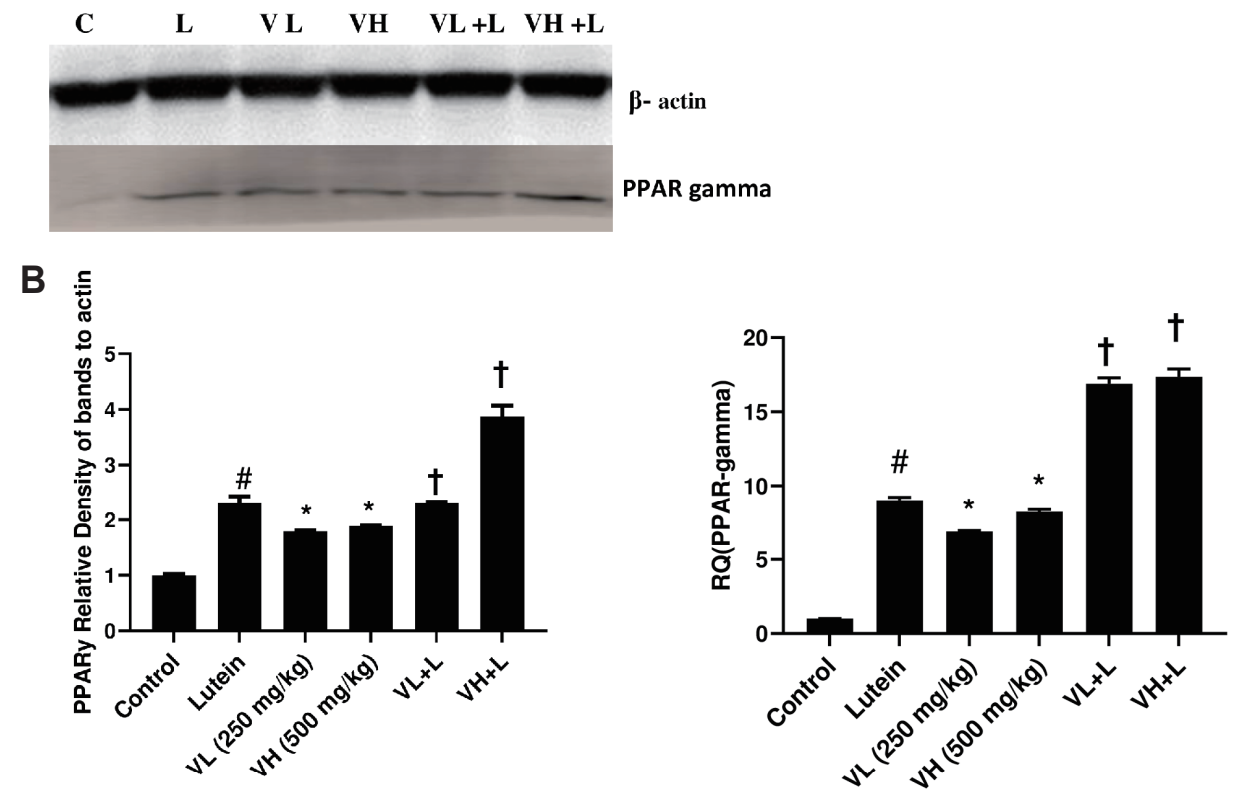

C
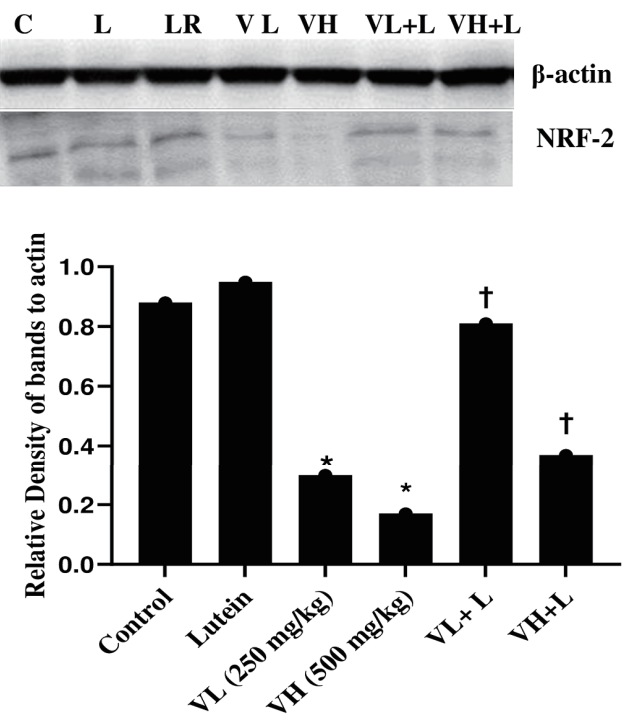

Fig. 3. Effect of lutein on (A) peroxisome proliferator-activated receptor gamma (PPARy), (B) peroxisome proliferator-activated receptor gamma (PPAR $y$ ) mRNA and (C), nuclear factor erythroid 2-related factor 2 (Nrf2) expressions respectively, in low $(250$ $\mathrm{mg} / \mathrm{kg}$ ) and high $(500 \mathrm{mg} / \mathrm{kg})$ dose vancomycin-induced renal injury in mice. Results are represented as mean \pm $\mathrm{SD}$. L, lutein; VL, $250 \mathrm{mg} / \mathrm{kg}$ vancomycin; $\mathrm{VH}, 500 \mathrm{mg} / \mathrm{kg}$ vancomycin; $\mathrm{VL}+\mathrm{L}, 250$ $\mathrm{mg} / \mathrm{kg}+$ lutein; $\mathrm{VH}+\mathrm{L}, 500 \mathrm{mg} / \mathrm{kg}+$ lutein. *Represent significant difference $(p<0.05)$ between control and vancomycin treated groups, while ${ }^{\dagger}$ represents significant difference $(p<0.05)$ between vancomycin treated and lutein plus vancomycin treatment groups. "Represents significant difference $(p<0.05)$ between control and lutein.

expression significantly, compared to that in the control group (Fig. 3A). In the mRNA expression analysis across the different treatment groups, the mRNA levels of PPAR $\gamma$ were found to be increased in the VL- and VH-treatment groups than those in the control group. Co-administration of lutein with either VL or VH significantly increased the mRNA expression of PPAR $\gamma$ in these renal tissues (Fig. 3B). Therefore, we conclude that lutein elevates the mRNA levels of PPAR $\gamma$ in the vancomycin-treatment groups. Western blotting analysis also showed a significantly reduced Nrf2 expression in both VL- and VH-treatment groups; however, in both the groups, the expression was restored with lutein treatment (Fig. 3C).

\section{Effect of lutein on NF-kB p65 expressions in vancomycin induced changes}

Results showed that NF- $\kappa \mathrm{B}$ p65expression was significantly elevated in both VL- and VH-treatment groups compared to that in the control group; however, co-administration with lutein reduced NF- $\mathrm{kB}$ p65 expression in both the groups (Fig. 4).

\section{DISCUSSION}

Vancomycin is an antibiotic used clinically to treat drug resistant bacterial infections, particularly by the gram-positive bacteria, MRSA. Reports indicate that, for clinical effectiveness, the daily area under the curve values of vancomycin should achieve 

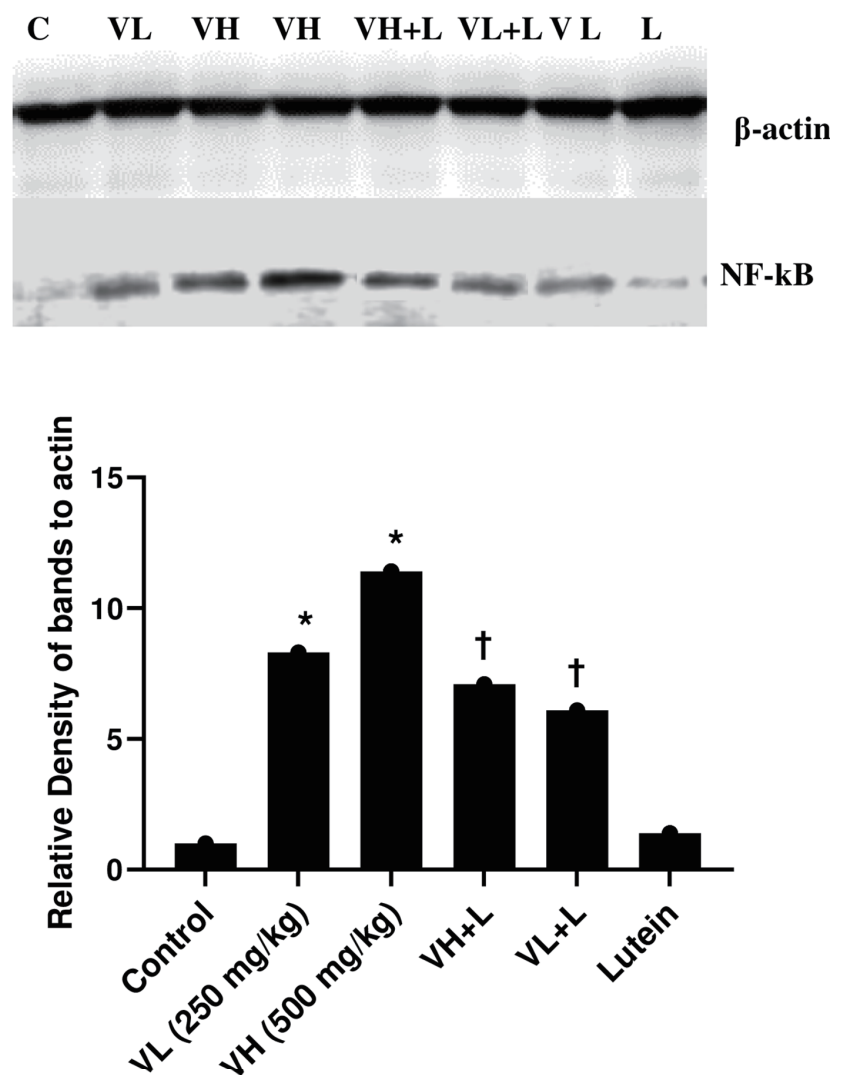

Fig. 4. Effect of lutein on nuclear factor-kappaB (NF-kB) expression in low $(250 \mathrm{mg} / \mathrm{kg})$ and high $(500 \mathrm{mg} / \mathrm{kg})$ dose vancomycininduced renal injury in mice. Results are represented as mean $\pm S D$. L, lutein; VL, $250 \mathrm{mg} / \mathrm{kg}$ vancomycin; $\mathrm{VH}, 500 \mathrm{mg} / \mathrm{kg}$ vancomycin; $\mathrm{VL}+\mathrm{L}$, $250 \mathrm{mg} / \mathrm{kg}$ + lutein; $\mathrm{VH}+\mathrm{L}=500 \mathrm{mg} / \mathrm{kg}$ + lutein. ${ }^{*}$ Represent significant difference $(p<0.05)$ between control and vancomycin treated groups, while ${ }^{\dagger}$ represents significant difference $(p<0.05)$ between vancomycin treated and lutein plus vancomycin treatment groups.

plasma concentrations of 400 and $600 \mathrm{mg} \times \mathrm{h} / \mathrm{L}$, respectively, via dose escalation [27]. As a result, there is a high concentration of free drug in the plasma, and dose escalation poses a cumulative risk for renal injury. Studies have shown various mechanisms for vancomycin-induced renal injury, suggesting that it could indeed be multifactorial in nature, involving several signaling transduction pathways $[2,16]$. However, no consensus on the mechanism has been reached. Improving the clinical outcome of vancomycin treatment is predicated on mitigating its associated nephrotoxicity.

In this study, we examined vancomycin-induced acute renal injury and its underlying mechanism. Moreover, we examined various signaling pathways involved in the generation of oxyradicals by vancomycin, and the inhibition of these oxyradicals by lutein-a natural antioxidant. Lutein has been reported to have a variety of biological effects related to its antioxidative properties [28]. The present findings indicate that the administration of lowdose and high-dose vancomycin in mice induces oxyradicals, leading to a significant reduction in the antioxidant activity in the renal tissues. In addition, co-administration of lutein with vancomycin restored the antioxidant levels, and consequently reduced the generation of cellular oxyradicals. Our data also showed that lutein administration led to a significant reduction in NAG excretion that was observed to increase after vancomycin treatment. The significantly increased NAG levels usually indicate cellular damage in the kidney, and this can be a sensitive biological marker for glycopeptide-antibiotic-induced renal toxicity [29]. Our findings are corroborated by an earlier study by Qu et al. [16] that showed increased NAG excretion in rats upon vancomycin administration $(200 \mathrm{mg} / \mathrm{kg})$. Lutein was found to reduce NAG levels and mitigate vancomycin-induced renal injury. In this study, a significant increase in creatine kinase activity was observed in the vancomycin-treatment groups, in a dose-dependent manner. Increased creatine kinase activity suggests muscle damage; therefore, is a marker for renal injury. In the present study, lutein co-administered with vancomycin, was observed to significantly decrease the levels of creatine kinase. Lutein has previously shown to decrease creatine kinase levels by $85 \%$ in $\mathrm{C}_{2} \mathrm{C}_{12}$ mice myocytes [30]. Ouyang et al. [31] also documented similar findings, wherein lutein administration lowered creatine kinase levels that were increased by isoproterenol administration in rats. According to Cheng et al. [32], lutein treatment significantly decreased the oxidative stress by reducing reactive oxygen species, protein carbonylation and sulphydryls, lipid peroxidation. Also, some studies indicated that low serum/plasma carotenoid levels are independently associated with sarcopenia and related muscle dysfunctions [33].

Furthermore, during renal injury, protein carbonyl content is known to usually increase. This can be used as another biomarker for cellular injury. Protein carbonyl content has been reported to be consistent in protein oxidative damage [34]. In this study, we observed that vancomycin treatment leads to elevated protein carbonyl content in a dose-dependent manner. However, our findings also show that lutein administration mitigated these effects, indicating that it has a protective role, in accordance with the findings of Cheng et al. [32]. Lipid peroxidation is a consequence of oxidative stress, and vancomycin treatment has been reported to significantly increase MDA levels in the renal tissues [16]. Our study also reports similar observations, although we show that lutein significantly reverses these effects. Evidence show that several drugs and diseases may affect blood flow and promote cell death via apoptosis, in the renal tissues [35]. Oxyradicals are reported to play a crucial role in renal injury, and consequently cell death via several pathways. In the present study, caspase-3 activity was evaluated as they are one of the main executors of apoptosis [36]. We found that administration of vancomycin at 250 and $500 \mathrm{mg} /$ $\mathrm{kg}$ increases caspase-3 protease activity in the renal tissues. These observations are similar to the findings of Yang et al. [36]. We also showed that lutein administration significantly reverses these effects. Our results are consistent with the findings of Ouyang et al. [31] and Nataraj et al. [37].

Through the histopathology examination of photomicrographs 
of renal tissues, this study confirms that different doses of vancomycin cause nephrotoxicity. We observed various hallmarks of renal injury, including inflammatory cells, leukocytes infiltration, necrosis, renal hypertrophy, and obliteration of renal tubules. However, upon lutein treatment, these effects were considerably reversed. This further goes to confirm that lutein has potent antioxidant and anti-inflammatory properties against oxyradicals. These findings are also consistent with other studies documented by Ouyang et al. [31] and Fung et al. [38].

It is well established that oxyradical generators like vancomycin induce oxidative stress [16]. Studies have shown that NF- $\kappa$ B, a transcriptional mediator of the inflammatory process, plays a key role in cellular injury and damage during this process [39].

In addition, NF- $\kappa \mathrm{B}$ has been tagged the "holy grail" of inflammatory processes, activating multiple pathways during cellular oxidative stress [40]. In a study conducted by Xiao et al. [41], indicated that NF- $\mathrm{\kappa B}$ pathway is induced during oxidative stress, producing inflammatory cytokines, chemokines, adhesive molecules and upregulating apoptotic signalling. This consequently leads to renal cell programmed death. Abundance evidence show that it causes DNA fragmentation and hence apoptosis via the activation of caspase 3 [42].

We also show that, vancomycin treatment leads to elevated expression of NF- $\mathrm{kB}$ p65 in a dose-dependent manner, and this correlates with tissue damage. These findings are similar to those reported by $\mathrm{Qu}$ et al. [16]. In the present study, lutein administration led to a dramatic reduction in NF- $\mathrm{B}$ p 65 expression, as indicated by the recovery of the parenchyma of the renal tubules.

Therefore, this study found that lutein supressed NF-кB p65 activation, thereby inhibiting its regulated gene products such as cytokines and caspase 3 . This finding is consistent with the reports of Buhrmann et al. [43], who used curcumin in same fashion.

Accumulative evidence shows that PPAR $\gamma$ plays a vital role in redox homeostasis by regulating several signaling pathways [11]. Therefore, the activation of PPAR $\gamma$ in the renal tissues could be critical for kidney functioning [44]. According to documented reports, the activation of PPAR $\gamma$ mitigates inflammation in various tissues; thereby, preventing cellular injury [11,44].

Numerous studies have shown that PPAR $\gamma$ agonists can be renoprotective by ameliorating inflammation [45]. Similarly, it has also been documented that, lutein has antioxidant properties, which suppress inflammatory responses, possibly through PPAR $\gamma$ activation [25]. The increased PPAR $\gamma$ expression upon vancomycin administration, in comparison to that in the control, can be explained as a compensatory measure by renal cells to overcome oxyradical-induced cellular damage. In this study, we also observed that the PPAR $\gamma$ expression increased with lutein administration, mitigating the effects of vancomycin-induced renal injury. These findings appear to be in agreement with those of Diep and Schiffrin [46]; they suggested that increased PPAR $\gamma$ expression might play a role in cell remodeling under stressful conditions. Kvandova et al. [47] also reported similar findings in spontaneously hypertensive rats, which evoked renal oxidative stress, but was attenuated by a PPAR $\gamma$ agonist. The activation of PPAR $\gamma$ under conditions of oxidative stress is linked to its ability to interact with the Nrf2 signaling pathway [48]. In this study, our findings show that vancomycin treatment led to the downregulation of $\mathrm{Nrf} 2$, which induced renal injury similar to that in previously reported studies [32]. However, lutein administration restored Nrf2 expression. There is abundant evidence showing that lutein acts by activating Nrf2, in addition to serving as a direct antioxidant. This suggests that there is a link between Nrf2 activation and PPAR $\gamma$ activity, which has been documented previously [48]. It has been reported that Nrf2-deficient mice lack protection from oxidants because Nrf2 modulates PPAR $\gamma$ [48].

However, another body of evidence show that PPAR $\gamma$ activation, in fact, regulates the Nrf2 pathway [49], owing to the evidence of reduced Nrf2 expression in PPAR $\gamma$-deficient mice [50]. Furthermore, the aforementioned studies strengthen our observation in the present study that lutein, an activator of PPAR $y$ and Nrf2, attenuates oxidative stress by increasing the expression of both. This view has been supported by many studies, indicating that co-activation of these pathways suppresses inflammation and cellular oxidative stress [51]. Moreover the attenuation of cellular expression of NF- $\mathrm{KB}$ by PPAR $\gamma$, and the suppression of proinflammatory mediators, is well documented [48]. Our study also showed a reduction in the NF- $\mathrm{\kappa B}$ expression on co-administration of lutein. This indicates that lutein may have a role in the mediation of antioxidant and anti-inflammatory activities observed in this study. Based on these results, we suggest that lutein upregulates PPAR $\gamma / \mathrm{Nrf2}$ signaling pathways and downregulates NF$\kappa \mathrm{B}$ signaling pathway. This finding was also corroborated by Makarov [52]. Jin et al. [53] clearly suggests that lutein inhibits NF$\kappa \mathrm{B}$ expression through the activation of PPAR $\gamma / \mathrm{Nrf} 2$ signaling pathways, which in turn mediates the expression of inflammatory genes [52]. These observations puts lutein in the category of PPAR gamma ligand. The effect of lutein is similar to the effects of PPAR gamma agonist. Pioglitazone, PPAR gamma agonist was found to significantly decrease acute renal injury induced by cisplatin model in mice [54]. Ibrahim et al. [55], also demonstrated this mediation in MTX-induced nephrotoxicity in rats. However, the combination of lutein and PPAR gamma agonist has not received much attention. Abundant evidence reveal that lutein acts by increasing the expression of PPAR gamma and hence could have a synergistic effect therapeutically as documented by Rafi et al. [56]. Observing that lutein showed mild decrease in cancer cell proliferation that improved in combination treatment with PPAR gamma agonists.

This study has highlighted the potential of lutein in protecting against vancomycin-induced renal injury, a major drawback of vancomycin treatment. In addition, this study confirms the antiinflammatory properties of lutein. The antioxidant activity of lutein is crucial in attenuating the effects of oxyradicals generated 
by vancomycin treatment; thereby, reducing oxidative stress, and consequently, mitigating renal cellular injury in mice. Lutein's renoprotective effects seem to be associated with increased PPAR $\gamma$ expression, and subsequent co-activation of Nrf2; hence, suppressing renal NF- $\mathrm{B}$ expression thereby inhibiting the activation of apoptotic process. Based on these observations, we suggest that the molecular mechanism of vancomycin-induced renal injury could be associated with the inhibition of PPAR $\gamma / \mathrm{Nfr} 2$ signaling pathways. We show that lutein can reactivate PPAR $\gamma / \mathrm{Nfr} 2$ signaling to attenuate the harmful effects of oxyradicals generated from the use of escalated doses of vancomycin.

\section{ACKNOWLEDGEMENTS}

We hereby wish to thank Deanship of Scientific Research, King Faisal University, Saudi Arabia for supporting this research. Also we wish to acknowledge Mr. Tameem Alyahian, our Laboratory Supervisor, for his assistance. We also acknowledge Mr. Sami Al-Qaimi for helping us with the procurement of chemicals.

This research project was funded by the Deanship of Scientific Research, King Faisal University, Saudi Arabia (grant number: 140237).

\section{CONFLICTS OF INTEREST}

The authors declare no conflicts of interest.

\section{REFERENCES}

1. Jorgensen SCJ, Murray KP, Lagnf AM, Melvin S, Bhatia S, Shamim MD, Smith JR, Brade KD, Simon SP, Nagel J, Williams KS, Ortwine JK, Veve MP, Truong J, Huang DB, Davis SL, Rybak MJ. A multicenter evaluation of vancomycin-associated acute kidney injury in hospitalized patients with acute bacterial skin and skin structure infections. Infect Dis Ther. 2020;9:89-106.

2. Dieterich C, Puey A, Lin S, Swezey R, Furimsky A, Fairchild D, Mirsalis JC, Ng HH. Gene expression analysis reveals new possible mechanisms of vancomycin-induced nephrotoxicity and identifies gene markers candidates. Toxicol Sci. 2009;107:258-269.

3. Lodise TP, Lomaestro B, Graves J, Drusano GL. Larger vancomycin doses (at least four grams per day) are associated with an increased incidence of nephrotoxicity. Antimicrob Agents Chemother. 2008;52:1330-1336.

4. Rybak M, Lomaestro B, Rotschafer JC, Moellering R Jr, Craig W, Billeter M, Dalovisio JR, Levine DP. Therapeutic monitoring of vancomycin in adult patients: a consensus review of the American Society of Health-System Pharmacists, the Infectious Diseases Society of America, and the Society of Infectious Diseases Pharmacists. Am J Health Syst Pharm. 2009;66:82-98.

5. Qin X, Tsoi MF, Zhao X, Zhang L, Qi Z, Cheung BMY. Vancomycin-associated acute kidney injury in Hong Kong in 2012-2016.
BMC Nephrol. 2020;21:41.

6. Nishino Y, Takemura S, Minamiyama Y, Hirohashi K, Ogino T, Inoue M, Okada S, Kinoshita H. Targeting superoxide dismutase to renal proximal tubule cells attenuates vancomycin-induced nephrotoxicity in rats. Free Radic Res. 2003;37:373-379.

7. Suntres ZE. Liposomal antioxidants for protection against oxidantinduced damage. J Toxicol. 2011;2011:152474.

8. Ratliff BB, Abdulmahdi W, Pawar R, Wolin MS. Oxidant mechanisms in renal injury and disease. Antioxid Redox Signal. 2016;25:119-146.

9. Stanton RC. Oxidative stress and diabetic kidney disease. Curr Diab Rep. 2011;11:330-336.

10. Kim JE, Clark RM, Park Y, Lee J, Fernandez ML. Lutein decreases oxidative stress and inflammation in liver and eyes of guinea pigs fed a hypercholesterolemic diet. Nutr Res Pract. 2012;6:113-119.

11. Ma Y, Shi M, Wang Y, Liu J. PPAR $\gamma$ and its agonists in chronic kidney disease. Int J Nephrol. 2020;2020:2917474.

12. Korbecki J, Bobiński R, Dutka M. Self-regulation of the inflammatory response by peroxisome proliferator-activated receptors. Inflamm Res. 2019;68:443-458.

13. Selvaraj RK, Klasing KC. Lutein and eicosapentaenoic acid interact to modify iNOS mRNA levels through the PPARgamma/RXR pathway in chickens and HD11 cell lines. J Nutr. 2006;136:1610-1616.

14. Zhang B, Lo C, Shen L, Sood R, Jones C, Cusmano-Ozog K, ParkSnyder S, Wong W, Jeng M, Cowan T, Engleman EG, Zehnder JL. The role of vanin-1 and oxidative stress-related pathways in distinguishing acute and chronic pediatric ITP. Blood. 2011;117:45694579.

15. García-Rojas P, Antaramian A, González-Dávalos L, Villarroya F, Shimada A, Varela-Echavarría A, Mora O. Induction of peroxisomal proliferator-activated receptor gamma and peroxisomal proliferator-activated receptor gamma coactivator 1 by unsaturated fatty acids, retinoic acid, and carotenoids in preadipocytes obtained from bovine white adipose tissue1,2. J Anim Sci. 2010;88:1801-1808.

16. Qu S, Dai C, Lang F, Hu L, Tang Q, Wang H, Zhang Y, Hao Z. Rutin attenuates vancomycin-induced nephrotoxicity by ameliorating oxidative stress, apoptosis, and inflammation in rats. Antimicrob Agents Chemother. 2018;63:e01545-e01518.

17. Nakamura T, Hashimoto Y, Kokuryo T, Inui KI. Effects of fosfomycin and imipenem/cilastatin on nephrotoxicity and renal excretion of vancomycin in rats. Pharm Res. 1998;15:734-738.

18. Vasudeva V, Tenkanidiyoor YS, Peter AJ, Shetty J, Lakshman SP, Fernandes R, Patali KA. Radioprotective efficacy of lutein in ameliorating electron beam radiation-induced oxidative injury in Swiss albino mice. Iran J Med Sci. 2018;43:41-51.

19. Horak E, Hopfer SM, Sunderman FW Jr. Spectrophotometric assay for urinary N-acetyl-beta-D-glucosaminidase activity. Clin Chem. 1981;27:1180-1185.

20. Hughes BP. A method for the estimation of serum creatine kinase and its use in comparing creatine kinase and aldolase activity in normal and pathological sera. Clin Chim Acta. 1962;7:597-603.

21. Velmurugan G, Venkatesh Babu DD, Ramasamy S. Prolonged monocrotophos intake induces cardiac oxidative stress and myocardial damage in rats. Toxicology. 2013;307:103-108.

22. Ohkawa H, Ohishi N, Yagi K. Assay for lipid peroxides in animal tissues by thiobarbituric acid reaction. Anal Biochem. 1979;95:351358. 
23. Rojas-Franco P, Franco-Colín M, Camargo MEM, Carmona MME, Ortíz-Butrón M del R E, Blas-Valdivia V, Cano-Europa E. Phycobiliproteins and phycocyanin of Arthrospira maxima (Spirulina) reduce apoptosis promoters and glomerular dysfunction in mercuryrelated acute kidney injury. Toxicol Res Appl. 2018;2:1-10.

24. Ahn SY, Cho CH, Park KG, Lee HJ, Lee S, Park SK, Lee IK, Koh GY. Tumor necrosis factor-alpha induces fractalkine expression preferentially in arterial endothelial cells and mithramycin A suppresses TNF-alpha-induced fractalkine expression. Am J Pathol. 2004;164:1663-1672.

25. Selvaraj RK, Shanmugasundaram R, Klasing KC. Effects of dietary lutein and PUFA on PPAR and RXR isomer expression in chickens during an inflammatory response. Comp Biochem Physiol A Mol Integr Physiol. 2010;157:198-203.

26. Livak KJ, Schmittgen TD. Analysis of relative gene expression data using real-time quantitative PCR and the $2^{-\triangle \Delta C T}$ method. Methods. 2001;25:402-408.

27. Rybak MJ, Le J, Lodise TP, Levine DP, Bradley JS, Liu C, Mueller BA, Pai MP, Wong-Beringer A, Rotschafer JC, Rodvold KA, Maples HD, Lomaestro BM. Therapeutic monitoring of vancomycin for serious methicillin-resistant Staphylococcus aureus infections: a revised consensus guideline and review of the American Society of HealthSystem Pharmacists, the Infectious Diseases Society of America, the Pediatric Infectious Diseases Society, and the Society of Infectious Diseases Pharmacists. Pharmacotherapy. 2020;40:363-367.

28. Liu ZG, Qi ZC, Liu WL, Wang WZ. Lutein protects against ischemia/reperfusion injury in rat kidneys. Mol Med Rep. 2015;11:21792184.

29. Yoshiyama Y, Yazaki T, Wong PC, Beauchamp D, Kanke M. The effect of fosfomycin on glycopeptide antibiotic-induced nephrotoxicity in rats. J Infect Chemother. 2001;7:243-246.

30. Nair SV, Ghanam K, Deshpande J, Juturu V. Lutein and zeaxanthin isomers induces mitochondrial biogenesis and improves endurance capacity in muscle cells. EC Ophthalmol. 2018;9:658-668.

31. Ouyang B, Li Z, Ji X, Huang J, Zhang H, Jiang C. The protective role of lutein on isoproterenol-induced cardiac failure rat model through improving cardiac morphology, antioxidant status via positively regulating Nrf2/HO-1 signalling pathway. Pharm Biol. 2019;57:529535.

32. Cheng F, Zhang Q, Yan FF, Wan JF, Lin CS. Lutein protects against ischemia/reperfusion injury in rat skeletal muscle by modulating oxidative stress and inflammation. Immunopharmacol Immunotoxicol. 2015;37:329-334.

33. Buonocore D, Rucci S, Vandoni M, Negro M, Marzatico F. Oxidative system in aged skeletal muscle. Muscles Ligaments Tendons J. 2012;1:85-90.

34. Kim DH, Kwack SJ, Yoon KS, Choi JS, Lee BM. 4-hydroxynonenal: a superior oxidative biomarker compared to malondialdehyde and carbonyl content induced by carbon tetrachloride in rats. J Toxicol Environ Health A. 2015;78:1051-1062.

35. Havasi A, Borkan SC. Apoptosis and acute kidney injury. Kidney Int. 2011;80:29-40.

36. Yang B, El Nahas AM, Thomas GL, Haylor JL, Watson PF, Wagner B, Johnson TS. Caspase-3 and apoptosis in experimental chronic renal scarring. Kidney Int. 2001;60:1765-1776.

37. Nataraj J, Manivasagam T, Thenmozhi AJ, Essa MM. Lutein protects dopaminergic neurons against MPTP-induced apoptotic death and motor dysfunction by ameliorating mitochondrial disruption and oxidative stress. Nutr Neurosci. 2016;19:237-246.

38. Fung FK, Law BY, Lo AC. Lutein attenuates both apoptosis and autophagy upon cobalt (II) chloride-induced hypoxia in rat Müller cells. PLoS One. 2016;11:e0167828.

39. Yamashita M, Yoshida T, Suzuki S, Homma K, Hayashi M. Podocyte-specific NF- $\kappa \mathrm{B}$ inhibition ameliorates proteinuria in adriamycin-induced nephropathy in mice. Clin Exp Nephrol. 2017;21:16-26.

40. Lawrence T. The nuclear factor NF-kappaB pathway in inflammation. Cold Spring Harb Perspect Biol. 2009;1:a001651.

41. Xiao Z, Shan J, Li C, Luo L, Lu J, Li S, Long D, Li Y. Mechanisms of cyclosporine-induced renal cell apoptosis: a systematic review. Am J Nephrol. 2013;37:30-40.

42. Jung ME, Gatch MB, Simpkins JW. Estrogen neuroprotection against the neurotoxic effects of ethanol withdrawal: potential mechanisms. Exp Biol Med (Maywood). 2005;230:8-22.

43. Buhrmann C, Mobasheri A, Busch F, Aldinger C, Stahlmann R, Montaseri A, Shakibaei M. Curcumin modulates nuclear factor kappaB (NF-kappaB)-mediated inflammation in human tenocytes in vitro: role of the phosphatidylinositol 3-kinase/Akt pathway. J Biol Chem. 2011;286:28556-28566.

44. Corrales P, Izquierdo-Lahuerta A, Medina-Gómez G. Maintenance of kidney metabolic homeostasis by PPAR gamma. Int J Mol Sci. 2018;19:2063.

45. Zhang YF, Wang Q, Su YY, Wang JL, Hua BJ, Yang S, Feng JX, Li HY. PPAR- $\gamma$ agonist rosiglitazone protects rat peritoneal mesothelial cells against peritoneal dialysis solution-induced damage. Mol Med Rep. 2017;15:1786-1792.

46. Diep QN, Schiffrin EL. Increased expression of peroxisome proliferator-activated receptor-alpha and -gamma in blood vessels of spontaneously hypertensive rats. Hypertension. 2001;38:249-254.

47. Kvandova M, Barancik M, Balis P, Puzserova A, Majzunova M, Dovinova I. The peroxisome proliferator-activated receptor gamma agonist pioglitazone improves nitric oxide availability, renin-angiotensin system and aberrant redox regulation in the kidney of prehypertensive rats. J Physiol Pharmacol. 2018;69:231-243.

48. Cho HY, Gladwell W, Wang X, Chorley B, Bell D, Reddy SP, Kleeberger SR. Nrf2-regulated PPAR $\gamma$ expression is critical to protection against acute lung injury in mice. Am J Respir Crit Care Med. 2010;182:170-182.

49. Lee C. Collaborative power of Nrf2 and PPAR $\gamma$ activators against metabolic and drug-induced oxidative injury. Oxid Med Cell Longev. 2017;2017:1378175.

50. Hayes JD, Dinkova-Kostova AT. The Nrf2 regulatory network provides an interface between redox and intermediary metabolism. Trends Biochem Sci. 2014;39:199-218.

51. Mahmoud AM, Germoush MO, Alotaibi MF, Hussein OE. Possible involvement of Nrf2 and PPAR $\gamma$ up-regulation in the protective effect of umbelliferone against cyclophosphamide-induced hepatotoxicity. Biomed Pharmacother. 2017;86:297-306.

52. Makarov SS. NF-kappaB as a therapeutic target in chronic inflammation: recent advances. Mol Med Today. 2000;6:441-448.

53. Jin XH, Ohgami K, Shiratori K, Suzuki Y, Hirano T, Koyama Y, Yoshida K, Ilieva I, Iseki K, Ohno S. Inhibitory effects of lutein on endotoxin-induced uveitis in Lewis rats. Invest Ophthalmol Vis Sci. 2006;47:2562-2568.

54. Jesse CR, Bortolatto CF, Wilhelm EA, Roman SS, Prigol M, Noguei- 
ra CW. The peroxisome proliferator-activated receptor- $\gamma$ agonist pioglitazone protects against cisplatin-induced renal damage in mice. J Appl Toxicol. 2014;34:25-32.

55. Ibrahim MA, El-Sheikh AA, Khalaf HM, Abdelrahman AM. Protective effect of peroxisome proliferator activator receptor (PPAR)- $\alpha$ and $-\gamma$ ligands against methotrexate-induced nephrotoxicity. Immunopharmacol Immunotoxicol. 2014;36:130-137.

56. Rafi MM, Kanakasabai S, Gokarn SV, Krueger EG, Bright JJ. Dietary lutein modulates growth and survival genes in prostate cancer cells. J Med Food. 2015;18:173-181. 